\title{
Media Post-coloniality and the Ethereal Persian 'Empress': How Hollywood Weaponized the Nostalgia of Exile
}

\author{
Sarah Boroujerdi ${ }^{1}$ \\ ${ }^{1}$ Department of Humanities and Social Sciences, State Center Community College District, Fresno, CA, United States \\ Correspondence: Sarah Boroujerdi, Department of Humanities and Social Sciences, State Center Community College \\ District, Fresno, CA, United States.
}

Received: September 22, 2021

Accepted: October 14, $2021 \quad$ Available online: November 6, 2021

doi:10.11114/ijsss.v9i6.5393

URL: https://doi.org/10.11114/ijsss.v9i6.5393

The more one is able to leave one's cultural home, the more easily is one able to judge it, and the whole world as well, with the spiritual detachment and generosity necessary for true vision.

—Edward Said, Orientalism

\begin{abstract}
The osmosis between Iranian exile, Oriental repertoires, and the commodification of nostalgia in film and contemporary ${ }^{1}$ culture alludes to the Disney reproduction of the East that is capitalized by Hollywood's invisible hand. The commodification of Orientalist logic via nostalgia of old civilization and Achaemenid grandeur is conveyed by Hamid Naficy's (1991) reference to Edward Said's (1978) 'imaginary ${ }^{2}$ geography' - the inventive tool of narration that augments tales and anecdotes of exilic narratives, while heightening essentialism of the East. The European modeling of coronation, bejeweled scepters of royalty under the Pahlavi period (1941-1979), and cinematic repertoires of Iranians in film are perpetuated for viewers via fetishization, lust, and enchantment. The televised 1967 coronation of Queen Farah (b. 1938) solidified the trope of the Persian 'Empress' through picturesque markers of Achaemenid rulership (550-330 BCE). Media ${ }^{3}$ propagations of nostalgia in the paradisiacal Pahlavi coronation can be paralleled to current illusions of the Orient presented in the film Paterson (Jarmusch, 2016), starring exiled Iranian actress Golshifteh Farahani. I refer to the Pahlavi coronation to expand on the spectacle of 'nostalgia', and the desire for a distant homeland. Naficy's (1991) interpretation of 'nostalgia' - a factor of exile, expounds how relics and objects induce a longing for the distant and ahistorical. Objects of nostalgia are inexplicably weaponized in Hollywood inventions of Near Eastern characters and serve as palpable symbols of the East via skewed representations of women, sexuality, and the exotic ${ }^{4}$ (Ahmed, 2006). Poetry, nostalgia, and fictional tales of the Orient in Paterson (Jarmusch, 2016) allude to Said's (1978) vision of the imperialist project in Orientalism. The inventive and imaginary power of color media in the televised Pahlavi coronation and the fashioning of a politically permanent subject of interest-Iranians and the East, augured a pertinent era of media post-coloniality ${ }^{\frac{5}{}}$ via the preservation of orientalism, rather than the Orient.
\end{abstract}

Keywords: orient, postcolonialism, imperialism, orientalism, Pahlavi, nostalgia, exile, poetry, return, homeland

\section{Introduction}

The nostalgia of regal history dating back to Cyrus the Great's founding of the Persian Empire (559 B.C.), fastforwarding to the pseudo-modernism of the 1967 Pahlavi coronation presented European emulations of imperial majestry and Orientalist logic. The coronation of Queen Farah served as the example of ancient and regal idolization-a spectacle of nostalgia promoting love of homeland through dysphoric Iranian affinity to the past. The practice of crowning under "glistening chandeliers... and Persian carpets" to "rays of diamonds" modeling traditional monarchy of the Sasanians presented a step back to tradition, and a step forward to the cosmos of ahistorical void (Steele, 2021, p. 179, 185). The 1967 coronation showed imitations of not just King Shapur's (309-379 A.D.) rulership, but of European self-crowning similar to that of Napoleon in 1804 (Steele, 2021, p. 175-179). "European presence reflected the royal family's European tastes, but also the shah's desire to prove that he was no less majestic than his European counterparts" (Amanat, 2017, p. 666; as cited in Steele, 2021). The color film of European coronation utilized by Iranian ambassadors in 1966 set the precedent of what the Pahlavi coronation unwittingly reflected - quintessential and pseudo-modern imperialism (Steele, 2021, p. 182). The Pahlavi monarchy's attempt to "adapt, evolve, and ultimately lead Iran into the modern world" suggests the tension to imitate European imperialist discourse—one stressed by Said's 
theory of Orientalism. The regality of the coronation spectacle heightened the essentialism of Central Asia and overarching Orientalist logic through the imperial couple's taste for all things grand and modern, yet ancient and regal (Steele, 2021, p. 184-5). The reliance on archival rulership of the Achaemenids set the tone of regality through diamonds, emeralds, and sapphires - all adding tangible and visual momentum to the Oriental idioms entering the Western press in the 1970s (Steele, 2021, p. 179, 191).

\subsection{The Šhabānū: An Image of Pre-Revolutionary Persia}

When referring to Near Eastern renditions and pre-revolutionary Persian nobility, the 1967 Pahlavi coronation mirrored an era of Eastern regality that was influenced by European courtship (Steele, 2021). Queen Farah Pahlavi (b. 1938) the Šhabānu,, exhibited a romanticized portrayal of the Persian 'Empress', garnering audiences worldwide with an heir of grandeur and political idolization. With a wardrobe of former European couturiers and local Iranian fabrics, Queen Farah reinstated a newfound national pride not seen during the elder Reza Shah's (d. 1944) reign ("Farah: The Working Empress," 1974). The Šhabānū represented the construction of a modern Pahlavi family "disguised in pseudo-historical terms" (Emami, 2011). The dripping gold and ethereal jewels-a historically nuanced yet undeviating symbol of Achaemenid aristocracy, eclipsed the nation's socioeconomic failures while propagating grandeurs of the Near East. This materialist conception of history through the Šhabānū's wardrobe unraveled her role as an intermediary between the economically less developed Iran, and the obtrusive Western media (Kopf, 1980, p. 495).

\subsection{The 'Custodian' of a Forgotten Empire and Cinematic Repertoires}

According to Robert Steele (2021) of the Department of Near Eastern Languages and Cultures at the University of California, Los Angeles, "every aspect of the event was designed to convey the idea that the shah was at once traditional and modern; the custodian of a 2,500-year-old tradition of monarchy, and a revolutionary" (p. 175). The world was reminded of the sepulchers of Persepolis, and of a forgotten empire once covering the Indus to the Mediterranean (Volney, 1890). The repercussions of 1800s modernity and Westernization, conjoined with economic turbulences of the 1963 White Revolution, penetrated the Iranian psyche and associated Pahlavi grandeur with "Achaemenid molding," romanticism, and nostalgia (Steele, 2021, p. 181; Naficy, 1991). Pompous portrayals of timeless rulership by the 'custodian' Reza Pahlavi, and Queen Farah's hopes to "avoid the mistakes" of developing countries circumvented the attention of the West from Iran's rigid financial woes ${ }^{7}$ (Billington, 1975; Zangeneh, 2015). With the wave of media postcolonialism following the rising popularity of Queen Farah in the 1960s and 1970s, the parallels between the borrowed modeling of European coronation, and concomitant cinematic repertoires of Iranians in film became mythicized and reproduced by television for consumers in the decades to follow.

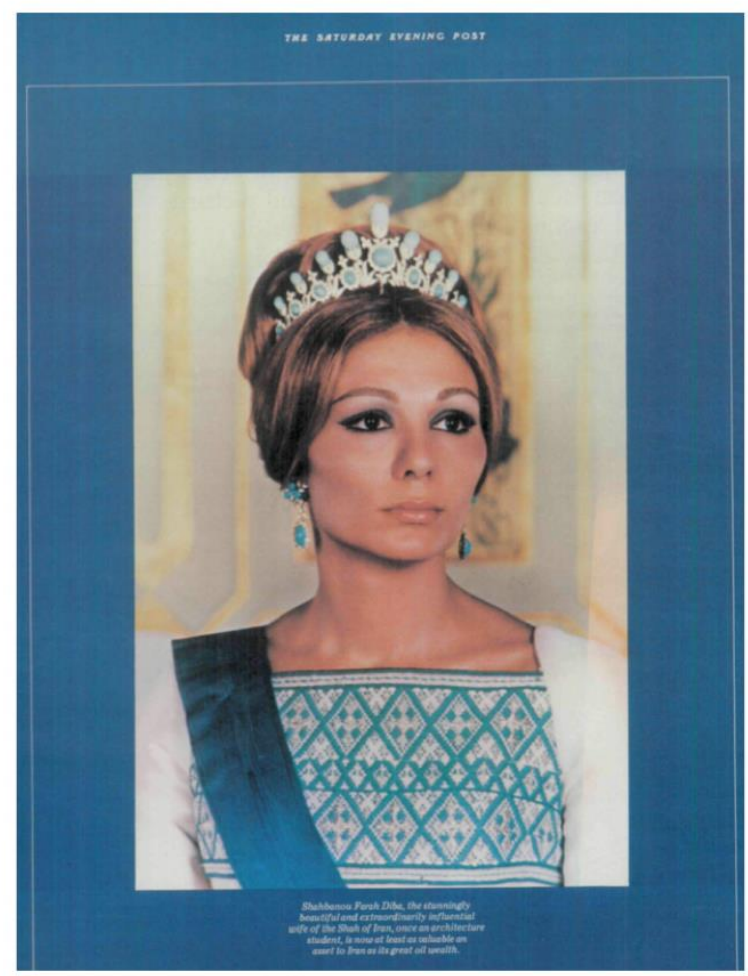

Figure 1. Queen Farah Pahlavi (Shahbanu Fara Diba)

Description: The Šhabānū representing an image of modernity and ethereal beauty. 


\subsection{The Pahlavi 'Empress' and Theorized Oppression}

Queen Farah embodied a youthful manifestation of the East - one through televised imagery of the exotic Persian juxtaposed to the modern. She captivated the global press and latched onto her dignified history-one rooted in grandeur of the Achaemenids. The reproduction of the enchanting and ethereal Persian 'Empress' highlighted archival remnants of scattered Iranian culture, privileging the East - and specifically Iran over other regions. Before her marriage to Mohammad Reza Shah, Queen Farah was a promising "leggy" architecture student in Paris, belonging to a semi-elite family of bureaucrats who instituted modernity in Teheran (Penziner, 2006; Billington, 1975). Western media depictions of the Pahlavi 'Empress' produced a product that was not of a specific space, domain, or place, but of the Orient. $\stackrel{8}{ }$ As viewers of the Pahlavi coronation fawned over the grandeurs of dripping glitter, gold, and jewels - one of cultured Persian rulers, Queen Farah became distanced from the suffering of Iranians and traversed into an ahistorical void. The nostalgia of pre-revolutionary Persian history with the first queen in Iran's 2,500-year history, and current mythical representations of Asia through anecdotal film references in Paterson (Jarmusch, 2016) compound and intersect to weaponize the narrative of nostalgia - a byproduct exile. The media narrative of Ancient Persia exemplified through regal modernity ${ }^{9}$ presented a break from the traditional and imperial aesthetics of Iran. Consider the attempt to reflect Queen Elizabeth's (1953) coronation with a crown weighing "close to 1.5 kilograms" (Steele, 2021, p. 182, 188). "The act of crowning his queen had more to do with advancing the perception of the shah as a modernizer" and "helped ingratiate the Iranian monarchy with the Western order" (Steele, 2021, p. 190). The imitations of not only European coronation, but of the theory of modernity and egalitarianism reflected the despotic governance of the Pahlavi era, an inability to relinquish the nationalist mentality, and a perpetuation of the Achaemenid fairytale. Consider Queen Farah's pseudo-modern wardrobe adopted from both Christian Dior and local Iranian threads, and coronation practices mirroring that of Queen Elizabeth (Steele, 2021, p. 188). Within this dynamic, the oppressed includes subjects of the East embodying forced integration into modernity, and internalizing the image of the oppressor via technique and Western ideas (Kopf, 1980, p. 501). The oppressor includes the producer of media imagery creating a monolithic historical reality of the Orient ${ }^{10}$ (Freire, 1970; Kopf, 1980, p. 499). This link between the oppressed and oppressor is reflective of Said's (1978) reference to the European discourse that is the essentialism of Central Asia-one fashioned through "Oriental character, Oriental despotism, Oriental sensuality, and the like" (Said, 1978, p. 203). Altogether, the coronation of Farah Diba was reminiscent to what one Turkish newspaper noted as "A Thousand and One Nights" (Steele, 2021, p. 190).

\section{Area Descriptors}

This section will expand on the inter-crossings between Oriental repertoires of the 1967 Pahlavi coronation, and current representations of the East find vindication via Hollywood imagery of the exotic. The film Paterson (Jarmusch, 2016) elaborates on the spectacle of the mythicized Orient via anecdotal references to Ancient Persia. Said's (1978) Orientalism will expound oppressive characterizations that stem from eighteenth-century settler-colonial accounts of Central Asia's pre-existing culture, civilization, and vast domain of "unknown lands" (Said, 1978). Meagan Morris's "Banality in cultural studies" will elaborate on character colloquialisms that sprout from media references of the Orient - such as those found in Paterson (Jarmusch, 2016). Hamid Naficy's "The Poetics and Practice of Iranian Nostalgia in Exile" will elaborate on nostalgia as a pre-existing factor resonating within the Iranian psyche —one fueled by lamentation, poetry, and desire for the distant homeland (Naficy, 1991).

\subsection{Exile and Poetry: A Love Story}

Consider the manifold portrayals by Golshifteh Farahani, an exiled Iranian actress in critically acclaimed cinema renditions within France and the United States. With her recent portrayal in Paterson (Jarmusch, 2016), Farahani plays Laura, spouse of Paterson (Adam Driver). In this sentimental and poetic New Jersey drama, Farahani embodies the figuration of the crafted Persian housewife living to serve as an aesthetic emblem of the Orient. Paterson, a New Jersey public bus driver, routinely spends his days overhearing passenger conversations of intimacy and anarchism, while reflectively observing his surroundings. He draws inspiration for love poems from the city landscape for his "secret notebook" (Jarmusch \& Quart, 2017). Laura (Farahani) spends her days creating juxtaposed white and black geometric designs around the home, and encourages Paterson to keep records of his poetry for a possible publication (Jarmusch et al., 2017). The love of poetry between Paterson and Laura reminds audiences of the affinity Iranians in exile hold to poetry, and the paradigm of exile operating within Farahani's actual forced departure from Iran. Farahani was an Iranian "de facto exile" in 2012 after posing for an artistic nude cover in promotion of the Cesars-a French equivalent of the Oscars (Gillis, 2012). Her versatile role as the spontaneous and crafty wife Laura in Paterson (Jarmusch, 2016) presents an inclination for her husband to continue drafting love poems. The story line of artistic passion is emblematic of exile and the singularity of desire for homeland - one conveyed through poetry prose. Poetry "provides a paradigmatic worldview of the language of exile, embodying a variety of journeys, returns, and unifications" (Naficy, 1991, p. 286). The Hollywood image and harmonious words of the charming Persian — Laura (Farahani), contextualizes 
and grounds what audiences understand as the exoticism of the Orient,, 11 and the dysphoria associated with separation from one's land.

\subsection{Silver Elephants and the Orientalist Project}

In one anecdotal reference from Paterson (Jarmusch, 2016), Laura (Farahani) lies bare in an overhead shot alongside her husband one morning (Jarmusch \& Quart, 2017). He admires her beauty, after which she recalls a dream.

Laura: I was dreaming we were in Ancient Persia. And you were riding an elephant.

A big, silver elephant.

Paterson: Did they have silver elephants in Ancient Persia?

Laura: I don't think so. Not silver ones anyway.

Laura's story of Persia is a reminder of the linear outcome cinema references propagate via abstractions and anecdotes. Here, Meaghan Morris's "Banality in Cultural Studies" refers to anecdotes as not an expression of a personal experience, but a mise en abyme $e^{\underline{I 2}}$ - a 'story within a story' (Morris, 1988). The audience nods at the familiar scene, the diverse casting, and thus reductively constructs a bridge between Laura's allegorical reference and the East, one of vast and nameless territory to be excavated, characterized, and invented by Hollywood. Tales of the Orient are consequently lost, leaving Western audiences to formatively characterize Laura (Farahani) as a remnant of 'Ancient Persia' through cinematography of the transnational imaginary $\underline{\underline{13}}$ — ahistorical constructions rooted in abstracted interactions and media characterizations. When Edward Said linked "the Orient" and "the Occident" (as cited in Hayford, 1978) as distinct poles, their role as part of the European political and literary mission may have foreshadowed the excavation and corporate reproduction of the East undertaken by cinema's invisible hand - one where the "Orient" is the embodied Persian 'Empress', and the "Occident" is the narrative that single-handedly weaponizes the Oriental trope. 'Orientalism' 14 - the comparative study of culture of the Orient, including the Near East, was persevered through "revolutions, world wars, and the literal dismemberment of empires" (Macey, 2001; Said, 1978). Orientalism was reminiscent of Foucauldian discursive formation, finding its origins in the justification of European colonial expansion. ${ }^{15}$ Knowledge of Central Asia was distilled into the West's consciousness. As Said (1978) recalls, "For the first time, the Orient was revealed to Europe in the materiality of its texts, languages, and civilizations. Also for the first time, Asia acquired a precise intellectual and historical dimension with which to buttress the myths of its geographic distance and vastness" (Said, et al., p. 77). The televised display of a nostalgic egotism and opulence of Achaemenid royalty through the 1967 Pahlavi coronation, and Farahani's anecdotal reference to 'Ancient Persia' in Paterson (Jarmusch, 2016) cross political boundaries via dreamlike images of the Orient, colloquialisms, and dysphoriaauthenticating the one-dimensionality in media renditions of Asia. 'Silver elephants' thus convey an interpretation of Central Asia on behalf of Western cinematic representations - for both the East and the West. Through the Orient's resignation $\frac{16}{}$ to the Occident's fetishes for vast Eastern terrains, audiences are led into a trancing and ahistorical voidone where Central Asia exists only in stories, anecdotes, and Western ideological constructions (Macey, 2001). The power to cinematically fashion 'Ancient Persia' as only remembered in dreams and colloquialisms alludes to the Hollywood political project that is the essentialism and obfuscation of the East—one based on its fullness, void of romance, sexuality, and sensuality. $\frac{17}{17}$

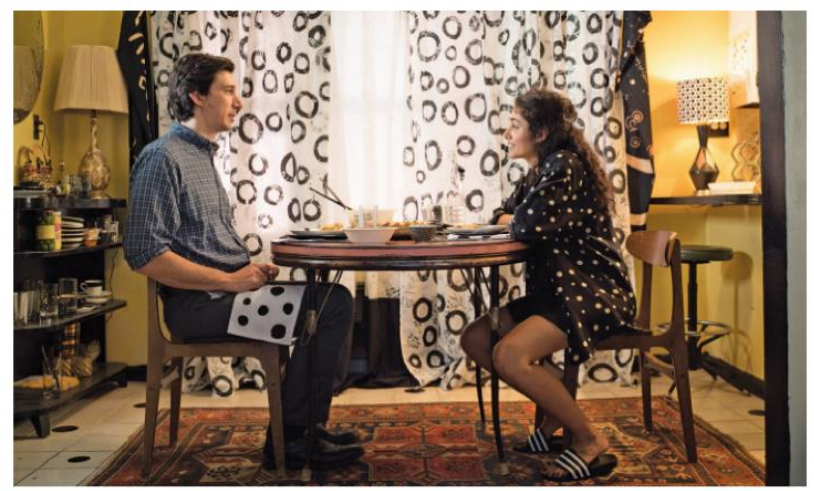

Figure 2. Still from film Paterson (Jarmusch, 2016)

Description: The intimate ensemble between Paterson and Laura in Paterson (Jarmusch \& Quart, 2017). 


\subsection{The Commodification of Nostalgia in Film and Contemporary Culture}

As Hamid Naficy (1991) describes in "The Poetics and Practice of Iranian Nostalgia in Exile," 'nostalgia' is a factor of exile, and has morphed into a discourse and "mode of representation" (p. 285). Both Queen Farah and Farahani furnish to audiences their love of the homeland. For Queen Farah, it was the heralding of a new Pahlavi age embodied through pompousness and glamour - a reminder of rich ancestry and wave of despotic governance covered by chauvinist materialism and emblematic nostalgia. For Farahani, it was her sentimental acting in Paterson (Jarmusch, 2016) that provided crossovers between axes of poetry and love of homeland with anecdotal references to Ancient Persia. As Naficy (1991) explains:

The same inability to "capture" the homeland is operative in exilic discourse; without distance, without separation, the nostalgic longing so prominent in exile would not be: "It is in this gap between resemblance and identity that nostalgic desire arises. The nostalgia is enamored of distance, not of the referent itself (S. Stewart 145, emphasis added). The "glorious return," the operative engine of actively maintained exile, must remain unrealized; in the words of Rumi, the exile must roam and pant to return but never actually achieve it (p. 288).

Paterson (Jarmusch, 2016) captures the longing for homeland through its rhyming motifs, artistic artifacts, anecdotes, and the love of poetry (Pinkerton, 2017; Slattery, 2017). Poetic nostalgia that "roams and pants" without actual return to the homeland alludes to Paterson's preservation of the Orient and envy of exilic narratives that are perpetuated via Western film (Naficy, 1991, p. 288; Jarmusch, 2016). With regards to geographic contextualization, the East is painted with signs of desire in how it is "known" to the West (Ahmed, 2006). With regards to geographic contextualization, the East is painted with signs of desire in how it is "known" to the West (Ahmed, 2006). When Said (1978) refers to Asia as strange, yet familiar, the spontaneous anecdotal reference to "Ancient Persia' creates a cohesion between the strange and familiar (Said, et al.; as cited in Ahmed, 2006). Media references to the Orient thus "domesticate" the East and bring it home to the viewer (Said, 1978). The televised and literary domestication of the East not only visually familiarizes it to the West, but reflects the drive to return to an imaginary homeland via film anecdotes and the poetry prose (Naficy, 1991).

\subsection{Orientalism as 'Corporate Identity'}

Said (1978) notes on institutional practices that convey the orientalist project, and refers to the "mythology of creation" that is catalyzed by artistic passion and intellect-altogether leading to less truth. He explains Orientalism as the corporate identity interwoven with "traditional learning" of classic literature and narratives of exploration that commodify the "exotic description" (Said, 1978, p. 202). This corporate identity of Orientalism leads the East to be understood in a distorted manner by its very systematization. Orientalism's role in the Hollywood project of mythicizing Central Asia, and anecdotes that result from exile become interpreted through their discrete representations and disconnections from the West-in both a geographic and pseudo-historical sense.

\section{Conclusions}

Neither Farahani nor Queen Farah may physically return to their homeland, yet they do so in vision. For Farahani, the reminder of homeland through dreaming of 'silver elephants' familiarized viewers with the distant desire of return that will never be tangibly grasped - only colloquially referenced. The imaginary geography of a nostalgic past is explained in "The Poetics and Practice of Iranian Nostalgia in Exile" by referencing Orientalism (as cited in Naficy, 1991):

...this nostalgic past is itself ideological in that, as Said writes in Orientalism (55), it has become an "imaginary geography," a construction created by exilic narratives. But this construction is not hermetic, since the "real" past threatens to reproduce itself as a lack or loss: it is against the threat of such a loss that the nostalgic past must be turned into a series of nostalgic objects, into fetish souvenirs that can be displayed and consumed repeatedly. Photo albums, letters, diaries, telephones, birds in flight, candles, rising smoke from cigarettes or from fog machines, the beach and the waves of the ocean...Images of people looking through photo albums, reading and writing letters in the light of a candle, of a burning cigarette smoking in an unattended ashtray, of loved ones conversing on the phone- these are the recurring micronarratives of nostalgic return (Naficy, 1991, p. 289).

Thus, objects fuel nostalgia through their palpable and consumable power. In Paterson (Jarmusch, 2016), Laura's 
husband attempts to pacify her wish to become a country singer. Paterson uses his hard-earned income to buy her an expensive guitar, one Laura excitedly uses to serenade him after practicing a country song. His poems are driven by basic references to Ohio Blue tip matches sitting on the counter, an ignited flame, bubbles fizzling out of an afternoon cold beer at a local bar in New Jersey, or an evening spent enjoying a black and white cinematic masterpiece. In all, "Paterson is a man whose mind drifts back and forth from what is in front of him to the words and images in his mind" (Jarmusch \& Quart, 2017). His nonchalant attention to Laura's dream of 'Ancient Persia', and the 'micronarratives of nostalgic return' are signified through remembered objects and a longing for the past (Naficy, 1991). The "imaginary geography" described by Said (1978) can be delineated in Paterson through Laura's anecdotal story and love for poetry—all fueling dysphoria, lamentation, and a desire to return (Said, et al.; Naficy, et al.).

\section{Discussion}

When discussing Orientalism in connection to current cinematic renditions, Edward Said is foremost a comparative literature professor, yet his scholarship serves as paramount to the discussion of media post-coloniality and underlying theories of imperialism. Orientalism presents specific moments of settler-colonial invasions through the lens of a Palestinian-American author who reconciles with misconstrued characterizations of the East that pervaded literature and Western conscience for the better half of the eighteenth, nineteenth, and twentieth centuries. To compare Said's work on the historical effects of imperialism - by that of the French and British over the Global South, to that of Hamid Naficy's scholarship within the field of post-colonial media studies in the most reductive sense would be unsubstantial to this work and to the respective authors, as each are guided by distinct backgrounds, domains, and fields critical to their respective decade. Consider Naficy's research performed over ten years of Iranian television and film (Naficy, 1991). Yet, both scholars 'academic findings reflect descriptions of Central Asia that are disseminated in the West via university transliterations. Naficy's (1991) interpretation of exile offers a glimpse into "inter-psychic" nostalgia and the affinity to poetry that survives through tangible reminders of the past. Nostalgia due to loss of homeland becomes the "representational practice among exiles" (Naficy, et al., p. 287). Said's (1978) explanation of French and British imperialism as recreating linear imaginations of the East is reflective of the power media holds among academic circles - one creating loss and augmentations of true representation. Orientalism would fall under the primary texts of post-colonial praxis and thinking, as Said's legacy of theoretical principles guided graduate-level critical theory well after his death. Post-colonial theory must not be confused with a time after colonization, but of the period within settlercolonialism, and the practices of conquest that have defined interpretations of the Orient and the subjugated 'other' (Macey, 2001). The renaming of Central Asia via media outlets is the argument posed by this paper. Synopses of nostalgia, Achaemenid imagery of the Pahlavi period, and current repertoires of Central Asia in Hollywood films all reflect what Said (1978) recalled as the "European discourse" and hermeneutic of Orientalism—one fashioned through imperialist mentality and idioms of the Orient (Said, 1978, p. 203; Kopf, 1980, p. 497). Thus, I expound post-colonial theory - the transnational aftermath of European colonialism (Macey, et al.). Further excavation into current media representations can be undone and interpreted, with orientalist images found in motion pictures of the twentieth and twenty-first century. Consider Hollywood's leading directors who have redefined Greco-Roman invasions of Central Asia with an heir of proclivity. Reimagined imperialist crossings with 'barbaric 'inhabitants of the East- such as that found in Indiana Jones and the Temple of Doom (Spielberg, 1984), or the artificial Bactrian dance in Alexander (Stone, 2004) are a few to name. As David Kopf (1980) notes in Hermeneutics versus History, “... a persisting and pervasive inability to see Asian civilizations without racial bias and cultural distortion is as much a result of the grandiose paradigms created by Western scholars and thinkers as of Western images of 'Asiaticks' found in newspapers and films" (Kopf, 1980, p. 498). Albeit, a critical review of current Hollywood illustrations of the Orient may fall within media criticism, diverging from the umbrella analysis of post-colonial theory and nostalgia that is the "historical narrative" of Pahlavi nobility (Steele, 2021, p. 192).

\section{Acknowledgements}

I would like to thank my previous graduate professors for their guidance on post-colonial theory and for emphasizing the importance of the subaltern and Third-World realities.

\section{References}

Ahmed, S. (2006). Queer phenomenology. Duke University Press.

Amanat, A. (2017). Iran: A Modern History. Yale University Press.

Ashcroft, B., Griffiths, G., \& Tiffin, H. (1989). The Empire writes back: Post-colonial literatures, theory and practice. https://doi.org/10.4324/9780203402627

Billington, J. (1975). The Shah's Advocate. Saturday Evening Post, 247(8), 10-13.

Emami, F. (2011). Civic visions, national politics, and international designs: three proposals for a new urban center in 
Tehran (1966-1976) (Doctoral dissertation, Massachusetts Institute of Technology).

Freire, P. (1970). Pedagogy of the Oppressed (MB Ramos, Trans.). New York: Continuum, 2007.

Gillis, C. (2012, September). From pride to pariah. Maclean's, 125(37), 37.

Hayford, E. R. (1978). Orientalism (Book Review). Library Journal, 103(19), 2247.

Jarmusch, J. (Director). (2016). Paterson [Film]. United States: Amazon Studios.

, \& Quart, L. (2017). Creating a Cinematic Prose Poem. Cineaste, 42(2), 28-30.

Kang, M., Lessard, D., Heston, L., \& Nordmarken, S. (2017). Introduction to women, gender, sexuality studies. Independent.

Kopf, D. (1980). Hermeneutics versus history. The Journal of Asian Studies, 39(3), 495-506.

Macey, D. (2001). Dictionary of Critical Theory. NY: Penguin Reference.

Morris, M. (1988). Banality in cultural studies. Discourse, 10(2), 3-29.

Naficy, H. (1991). The Poetics and Practice of Iranian Nostalgia in Exile. Diaspora: A Journal of Transnational Studies l(3), 285-302. https://doi.org/10.1353/dsp.1991.0025

Penziner, V. L. (2006). Selective omission: Inserting Farah Pahlavi and Jehan Sadat into the women's movements of Iran and Egypt. The University of Arizona.

Pinkerton, N. (2017). Paterson. Film Comment, 53(1), 47.

Said, E. (1978). Orientalism. (1979). Orientalism. New York: Vintage.

Schwab, R. (1934). Vie d'Anquetil-Duperron, suivie des Usages civils et religieux des Parses par Anquetil-Dupperron. E. Leroux.

Slattery, D. P. (2017). Film Review. Psychological Perspectives, 60(4), 505-510. https://doi.org/10.1080/00332925.2017.1390372

Spielberg, S. (Director). (1984). Indiana Jones and the Temple of Doom [Film]. United States: Paramount Pictures.

Steele, R. (2021). Crowning the "Sun of the Aryans": Mohammad Reza Shah's Coronation and Monarchical. Spectacle in Pahlavi Iran. International Journal of Middle East Studies, 53(2), 175-193. https://doi.org/10.1017/S002074382000121X

Stewart, K. (1992). Nostalgia-A Polemic. In G. Marcus (Ed.), Rereading Cultural Anthropology (pp. 252-266). New York, USA: Duke University Press. https://doi.org/10.1515/9780822397861-015

Stewart, S. (1984). On Longing: Narratives of the Miniature, the Gigantic, the Souvenir, the Collection (2nd ed.). Durham \& London.

Stone, O. (Director). (2004). Alexander [Film]. United States: Warner Bros. Pictures.

TIME Magazine. (1974, November 4). Farah: The Working Empress. TIME USA, LLC, 104(19), 36-36.

Volney, C. F. (1890). The Ruins: Or, Meditation on the Revolutions of Empires: and the Law of Nature. Peter Eckler Publishing Company.

Zangeneh, H. (2015). The Political Economy of Iran Under the Qajars: Society, Politics, Economics, and Foreign Relations. Journal of Urban Technology, 22(3), 126-129. https://doi.org/10.1080/10630732.2015.1054675

\section{Notes}

Note 1 . In reference to cultural productions of the post-war era, beginning with the countercultural wave affecting material and cinematic culture.

Note 2. The 'imaginary 'frees the imagination and provides the psyche an experience of openness, craft, and novelty. This is the element of daydreaming and poetic creation (Macey, 2001).

Note 3. "No advertisement, movie, or form of media has an inherent meaning that passes directly from the producer to the consumer of media. Meanings within media develop between consumers and the media product" (Kang, Lessard, Heston, \& Nordmarken, 2017).

Note 4. The East is associated with what is "behind and below the West, as well as what is on the other side" (Ahmed, 
2006, p. 14).

Note 5. Critiques of 'postcolonialism' recall colonialism and of civilizations that have been propagated by scholars within the Asian and Middle Eastern Diasporas (Kang, et al., 2017).

Note 6. Literal translation is "lady-king" (Emami, 2011), used in Middle Persian to describe female monarchs of the Sasanian period (224-651 C.E.) (Emami, et al.).

Note 7. Iran encountered a transition from feudalism to capitalism in the 1920s. Muhammad Reza Shah's White Revolution of 1963 attempted to regulate more equal class disparities but did little to change the social reality of Iran as a whole (Penziner, 2006).

Note 8. The Orient is understood as not of a specific place (Ahmed, 2006).

Note 9. In reference to the quality of being modern, and 'pertaining to today'. The term implies a break with or departure from something earlier, and is utilized as an opposite to 'traditional '(Macey, 2001).

Note 10. According to Pedagogy of the Oppressed, the theory of oppressive action involves a very direct truth. For the oppressor to oppress, a theory of oppressive action is necessary. The oppressed internalizes the image of the oppressor (Freire, 1970).

Note 11. The Orient can become known as infinite with 'infinite shape' (Said, 1978).

Note 12. French expression used to describe a small shield existing within a larger shield; utilized in both literature and visual arts. The saying represents self-reflexivity within postmodernist fiction (Macey, 2001).

Note 13. The 'imaginary 'structures existence, including the symbolic and the real (Macey, 2001).

Note 14. The discipline that studies the culture of the Orient, including the Islamic countries of the Near and Middle East. The term was coined by Edward W. Said, whose text Orientalism (1978) includes one of the founding texts of post-colonial theory (Macey, 2001).

Note 15. Abraham-Hyacinth Anquetil-Duperron (1731-1805) was an egalitarian who traveled to Asia to "prove the actual primitive existence" of its peoples (as cited in Said, 1978). His translation of the Avesta and expedition to Asia was described by Raymond Schwab. Schwab (1934) alluded to Anquetil's translation of Avesta as "correcting and expanding the old humanism of the Mediterranean basin," and came to the conclusion that European provinces were not the only sites to "have left their mark on history" (as cited in Said, 1978).

Note 16. The Orient is made oriental through its submission to the authority of the Occident (Ahmed, 2006).

Note 17. Ahmed (2006) refers to the fullness of the Orient, in that it is "not Europe," and pointing to a world of romance, sexuality, and sensuality (p. 114). 


\section{Appendix}

East

exile

imaginary

mise en abyme

modernity

Orient

Orientalism
Associated with what is "behind and below the West, as well as what is on the other side" (Ahmed, 2006, p. 14). The philosophy of phenomenology, a critical discipline of the twentieth century (Macey, 2001, p. 297).

In reference to peoples of Third World countries, whose loss of homeland leads to a fragmentation with time, reality, and history. Exiles face the "double loss" of "origin and of reality," leading to the cultural practice of nostalgia (Naficy, 1991, p. 285).

The element provides the psyche an experience of openness, craft, and novelty. Includes daydreaming and poetic creation (Macey, 2001). Not to be mistaken for imagination. Utilized in studies of poetics (Macey, 2001, p. 199).

A 'story within a story' (Morris, 1988). French expression describing a small shield existing within a larger shield; utilized in literature and visual arts. Represents self-reflexivity within postmodernist fiction (Macey, 2001, p. 256).

In reference to the quality of being modern, and 'pertaining to today'. The term implies a break with or departure from something earlier, and is utilized as an opposite to 'traditional' (Macey, 2001).

Opposite of the Occident. The Orient is made oriental through its submission to the authority of the Occident. Ahmed (2006) refers to the fullness of the Orient, in that it is "not Europe" and pointing to a world of romance, sexuality, and sensuality (Ahmed et al., p. 114). The Orient can become known as infinite with 'infinite shape' (Said, 1978).

The discipline that studies culture of the Orient, including Islamic countries of the Near and Middle East. Coined by Edward W. Said, whose text Orientalism (1978) includes one of the founding scholarship of post-colonial theory (Macey, 2001). According to Said (1978), 'Orientalism' is an

"academic tradition" - a field interpreted by travelers and consumers of "novels and accounts of exotic adventure" (p. 203). In a more critical sense, the "European discourse" of Orientalism was fashioned through essentialism of the East and idiom frequencies of the Orient (Said, 1978, p. 203). 
poetics

Post-colonial Literatures

post-colonial

Post-colonial Theory

Šhabānū

\section{Copyrights}

Copyright for this article is retained by the author(s), with first publication rights granted to the journal.

This is an open-access article distributed under the terms and conditions of the Creative Commons Attribution license which permits unrestricted use, distribution, and reproduction in any medium, provided the original work is properly cited.
Within the modern sense and usage, the term can refer to "general descriptive theory of literature" (Macey, 2001, p. 300). Associated with the theory of narratology and structuralism. The poetic function highlights the "formal devices that structure the message" (Macey, et al.).

This field originated within multiple stages and is correlated to domestic consciousness. Post-colonial literature describes the project that perpetuates and constructs a difference from the center that is imperialistic (Ashcroft, Griffiths, \& Tiffin, 1989).

Refers to periods within colonization, and cultures that were affected by the "imperial process" (as

Analyzes the transnational aftermath of European colonialism (Macey, 2001, p. 304). The term was broadly defined by The Empire Writes Back (Ashcroft, Griffiths, \& Tiffin, 1989). Studies cultures and writings of the Global South and of Asia. Through methodology, the theory is associated with postmodernity and discourse analysis stemming from Foucault. The skeptical authors within this realm include Edward Said and Gayatri Spivak.

Literal translation is "lady-king" (Emami, 2011), monarchs of the Sasanian period (224-651 C.E.) (Emami, et al.). cited in Ashcroft, Griffiths, \& Tiffin, 1989). used in Middle Persian to describe female 